\begin{tabular}{|l|l|r|}
\hline A1 Fitrah & \\
Journal Of Early Childhood Islamic Education & Kurangnya Bahasa Ekspresi Pada Anak \\
ISSN $:$ 2599-2287 E-ISSN $:$ 2622-335X & Usia 5 Tahun ... \\
Vol.2 No.2 Januari 2019 & Septi Fitriani \\
\hline
\end{tabular}

\title{
KURANGNYA BAHASA EKSPRESIF PADA ANAK USIA 5 TAHUN DI JL. RADEN FATAH NO 004 RT 01 KELURAHAN PAGAR DEWA, KECAMATAN. SELEBAR KOTA BENGKULU
}

\begin{abstract}
Abstrak
Bahasa memegang peranan penting dalam kehidupan manusia umumnya dan dalam kegiatan berkomunikasi khususnya. Bromley menyatakan kemampuan berbicara merupakan suatu ungkapan dalam bentuk kata-kata. Ada yang bersifat reseptif (dimengerti dan diterima) maupun ekspresif (dinyatakan). Anak Berbicara termasuk dalam kemampuan bahasa ekspresif. Pengembangan bicara anak yang dimaksud adalah usaha meningkatkan kemampuan anak untuk berkomunikasi secara lisan sesuai dengan situasi yang dimasukinya. Pengembangan kemampuan bicara anak pada dasarnya merupakan program kemampuan berpikir logis, sistematis, dan analitis dengan menggunakan bahasa sebagai alat untuk mengungkapkan gagasannya. Faktor yang mempengaruhi tergangunya bahasa ekspresif SP dikarenakan foktor internal yaitu genetik yaitu karena ibunya memiliki ganguan berbahasa dimana sang ibu juga memiliki permaslahan yaitu agak cadel dalam berbicara, kemudian faktor eksternal yaitu faktor lingkungan dimana SP tidak memiliki teman sebaya saat berumur 1-4 tahun, menjadikan SP kurang dalam berkomunikasi.
\end{abstract}

\section{Kata kunci: Bahasa Ekspresif}

\section{Pendahuluan}

Perkembangan adalah suatu proses untuk menuju kedewasaan pada makhluk hidup yang bersifat kualitatif, artinya tidak dapat dinyatakan dengan suatu bilangan tatapi dapat diamati dengan mata telanjang. Salah satu aspek penting dalam perkembangan adalah aspek perkembangan bahasa. Bahasa merupakan alat komunikasi yang sangat penting dalam kehidupan manusia karena disamping berfungsi sebagai alat untuk menyatakan pikiran dan perasaan kepada orang lain juga sekaligus
Septi Fitriana septifitriana@iainbengkulu.ac.id IAIN Bengkulu 


\begin{tabular}{|l|l|r|}
\hline & Al Fitrah & \\
Journal Of Early Childhood Islamic Education & Kurangnya Bahasa Ekspresi Pada Anak \\
ISSN : 2599-2287 E-ISSN : 2622-335X & Usia 5 Tahun ... \\
Vol.2 No.2 Januari 2019 & Septi Fitriani \\
\hline
\end{tabular}

bahasa baik secara lisan maupun tulisan. Masa kanak-kanak adalah masa yang paling tepat untuk mengembangkan bahasa. Pasalnya masa anak usia dini adalah masa emas seorang anak dimana pada masa inilah stimulasi-stimulasi sangat diperlukan.

Menurut Hurlock, perkembangan awal lebih penting dari pada perkembangan selanjutnya, karena dasar awal sangat dipengaruhi oleh belajar dan pengalaman. Demikian pula halnya peranan bahasa bagi anak.

Bahasa merupakan sarana yang efektif untuk menjalin komunikasi sosial. Sebagai alat yang sangat penting, bahsa memiliki fungsi yang signifikan bagi manusia. Paling tidak, ada dua fungsi bahasa. Pertama, bahasa sebagai sarana pembangkit dan pembangun hubungan yang memperluas pikiran seseorang sehingga kehidupan mentalnya menjadi bagian yang tidak terpisahkan dari mental kehidupan kelompok. Kedua, bahasa sebagai sarana yang memengaruhi kepribadian. ${ }^{1}$

Bahasa memberikan sumbangan yang pesat dalam perkembangan anak menjadi manusia dewasa. Pribadi itu berpikir, berperasaan, bersikap, berbuat serta memandang dunia dan kehidupan seperti masyarakat disekitarnya. Sehubungan dengan peranan penting bahasa dalam kehidupan. Holliday mengemukakan beberapa fungsi bahasa bagi anak. Fungsifungsi tersebut adalah sebagai berikut : (1) fungsi instrumental : bahasa digunakan sebagai alat perpanjangan tangan “ tolong ambilkan pensil”. (2) fungsi interaksional :

\footnotetext{
1 Rina Roudhotul Jannah,dkk.2018.144 Strategi Pembelajaran Anak Usia Dini Berbasis Multifel Intelligences. Yogyakarta:AR-RUZZ Media.hlm 3
}

bahasa digunakan untuk bersosialisasi "apa kabar ?”. (3) fungsi regulatif : bahasa digunakan untuk mengatur orang lain “ jangan ambil bukuku!”. (4) Fungsi personal : bahasa digunakan untuk mengungkapkan perasaan / pendapat “ saya se nang sekali”. (5) Fungsi Representatif : Bahasa digunakan untuk memberikan informasi / fakta “ sekarang hujan”. Jadi, bahasa merupakan medium yang paling penting dalam komunikasi manusia. Bahasa bersifat unik sekaligus bersifat universal bagi manusia.

Berdasarkan Standrat Tingkat Pencapaian Perkembangan (STTP) dalam Permendiknas No.58 Tahun 2009 untuk Lingkup Perkembangan Bahasa anak kelompok A ada tiga perkembangan yang harus dicapai anak antara lain : (1) Menerima Bahasa (2) Mengungkapkan Bahasa (3) Keaksaraan. Sedangkan Tingkat Pencapaian Perkembangan yang harus dicapai anak dalam bahasa 3 antara lain : Menyimak perkataan orang lain (bahasa ibu atau bahasa lainnya), Memahami cerita yang dibacakan, Mengenal perbendaharaan kata. Perkembangan bahasa anak usia 3-5 tahun adalah dimana anak sudah dapat berbicara dengan baik yaitu tidak dengan terbalik-balik. Anak mampu. Pada usia ini anak mulai senang mendengarkan cerita sederhana dan mulai banyak bercakap-cakap, benyak bertanya seperti apa, mengapa, bagaimana, juga dapat mengenal tulisan sederhana.

Campbell dan Dickinson (dalam sugiono), tujuan dari pengembangan bahasa adalah sebaga berikut: 1). Agar anak mampu berkomunikasi dengan baik; 2). 


\begin{tabular}{|l|l|r|}
\hline A1 Fitrah & \\
Journal Of Early Childhood Islamic Education & Kurangnya Bahasa Ekspresi Pada Anak \\
ISSN $:$ 2599-2287 E-ISSN $:$ 2622-335X & Usia 5 Tahun ... \\
Vol.2 No.2 Januari 2019 & Septi Fitriani \\
\hline
\end{tabular}

Memiliki kemampuan bahasa untuk meyakinkan orang; 3). Mampu mengingat dan menghafal informasi; 4). Mampu memberi penjelasa; 5). Mampu untuk membahas bahasa itu sendiri. ${ }^{2}$

Berdasarkan uraian di atas, maka dapat dipahami terdapat dua daerah pertumbuhan bahasa, yaitu bahasa yang bersifat pengertian/reseptif (understanding) dan pernyataan/ekspresif (producing). Pada Anak usia dini fase perkembangan bahsanya ialah fase bahasa ekspresif. Anak Usia dini sudah dapat berkomunikasi secara lisan. Aspek-aspek yang berkaitan dengan perkembangan bahasa lisan anak yaitu : (1) Kosa Kata : perkembangan anak dan pengalamannya berinteraksi dengan lingkungannya membuat kosa kata anak berkembangan dengan pesat. (2) Sintak (tata bahasa) : Walaupun anak belum mempelajari tata bahasa akan tetapi melalui contoh-contoh berbahasa yang didengar dan dilihat di lingkungannya, anak telah dapat menggunakan bahasa lisan dengan susunan kalimat yang baik. (3) Semantik/Arti : Penggunaan kata yang sesuai dengan tujuannya. Anak Taman Kanak-kanak sudah dapat mengekspresikan keinginan, penolakan dan pendapatnya dengan menggunakan kata-kata dan kalimat yang tepat. (4) Fonem (bunyi kata): Anak Taman Kanak-kanak sudah memiliki kemampuan untuk merangkai bunyi yang didengarnya menjadi satu kata yang me ngandung arti.

Pada kenyataannya anak usia dini rata-rata belum banyak menguasai kosa kata yang dijelaskan oleh para ahli. Terlihat

${ }^{2}$ Rina Roudhotul Jannah,dkk.2018. Strategi Pembelajaran Anak Usia Dini Berbasis Multiple Intelligences. Jakarta:Ar-ruzz Media.hal 3 dari cara berkomunikasi anak secara keseharianya di sekolah, kadang juga ada anak yang tidak mau berbicara jika ada pertanyaan dari guru atau dalam kegiatan lain, hal ini tentunya akan menghambat perkembangan bahasanya. Disinilah peran guru sangat dibutuhkan dalam mengembangkan bahasa anak terutama di sekolah.

\section{Kajian Teori}

\section{Kemampuan Bahasa Ekspresif}

Anak Berbicara termasuk dalam kemampuan bahasa ekspresif. Bromley ${ }^{3}$ menyatakan kemampuan berbicara merupakan suatu ungkapan dalam bentuk kata-kata. Ada yang bersifat reseptif (dimengerti dan diterima) maupun ekspresif (dinyatakan). Contoh bahasa ekspresif adalah berbicara dan menuliskan informasi untuk dikomunikasikan dengan orang lain. Gordon dan Browne dalam Dhieni ${ }^{4}$ menambahkan bahwa penguasaan berbahasa ekspresif adalah semakin seringnya anak menyatakan keinginan, kebutuhan, pikiran dan perasaan kepada orang lain secara lisan. Anak-anak yang fasih dalam kekampuan berbahasa lisan bisa mengkomunikasikan idenya dan mengajukan pertanyaan selama kegiatan pembelajaran. $^{5}$

Kemampuan bahasa ekspresif anak diusia 3-5 tahun menurut Steinberg dan

3 Nurbiana, Dhieni,. 2006. Metode Pengembangan Bahasa. Jakarta: Universitas Terbuka.hal19

4 Nurbiana, Dhieni,. 2006. Metode Pengembangan Bahasa. Jakarta: Universitas Terbuka. 7.5

${ }^{5}$ Beverly, Otto.2015.Perkembangan Bahasa Anak Usia Dini.Jakarta:Prenadamedia Grub.hal 23 


\begin{tabular}{|l|l|r|}
\hline & Al Fitrah & \\
Journal Of Early Childhood Islamic Education & Kurangnya Bahasa Ekspresi Pada Anak \\
ISSN : 2599-2287 E-ISSN : 2622-335X & Usia 5 Tahun ... \\
Vol.2 No.2 Januari 2019 & Septi Fitriani \\
\hline
\end{tabular}

Gleason $^{6}$ termasuk dalam perkembangan kombinatori dimana anak sudah mampu berbicara secara teratur dan terstruktur, pembicaraannya dapat dipahami oleh orang lain dan anak sanggup merespon baik positif maupun negatif atas pembicaraan lawan bicaranya. Hal ini sesuai dengan Sugono $^{7}$ yang menyatakan bahwa bahasa lisan atau bahasa ekspresif adalah bahasa yang dihasilkan dengan menggunakan alat ucap (Organ Of Speech) dengan fonem sebagai unsur dasarnya. Bahasa lisan mencakup aspek lafal, tata bahasa (bentuk akat dan susunan kalimat), dan kosakata.

Menurut Harris ${ }^{8}$ keterampilan berbahasa mempunyai empat komponen, yaitu : 1) keterampilan menyimak (listening skills); 2) keterampilan berbicara (speaking skills); 3) keterampilan membaca (reading skills); 4) keterampilan menulis (writing skills). Setiap keterampilan berhubungan erat dalam memperoleh keterampilan berbahasa. Suhartono ${ }^{9}$ mengungkapkan bahwa bicara anak adalah suatu penyampaian maksud tertentu dengan mengucapkan bunyi-bunyi bahasa supaya bunyi tersebut dapat dipahami oleh orang yang ada dan mendengar disekitarnya. Bunyi tangisan bayi sebenarnya juga mempunyai maksud tertentu, mungkin memanggil orang tuanya, mungkin

6 Suhartono. 2005. Pengembangan Keterampilan Bicara Anak usia Dini. Jakarta: Depdiknas.Hal 35

Nurbiana, Dhieni. 2006. Metode Pengembangan Bahasa. Jakarta: Universitas Terbuka.hal4.4

8 Tarigan, H.G. 2008. Berbicara sebagai Suatu Keterampilan Berbahasa. Bandung: Angkasa.hal 1

9 Suhartono. 2005. Pengembangan Keterampilan Bicara Anak usia Dini. Jakarta: Depdiknas.hal22 kedinginan, mungkin lapar, mungkin haus dan sebagainya.

Hampir semua bunyi yang diucapkan anak mempunyai maksud tertentu, walaupun bunyi tersebut bukan bunyi berbentu kata maupun kalimat. Jadi yang dimaksud bicara anak lebih luas maknanya dengan makna berbicara. Jika berbicara lebih diartikan sebagai pengucapan bunyi-bunyi bahasa yang dapat dipahami oleh lawan bicara, tetapi bicara anak lebih diartikan bunyi yang diucapkan oleh anak, baik bunyi bahasa maupun bunyi-bunyi yang bukan bahasa tetapi diucapkan oleh alat ucap anak. Definisi berbicara secara umum dapat diartikan suatu penyampaian maksud (ide, pikiran, gagasan, atau isi hati) seseorang kepada orang lain dengan menggunakan bahasa lisan sehingga maksud tersebut dapat dipahami oleh orang lain $^{10}$. Pengertian bicara secara khusus juga dikemukakan oleh Tarigan mengemukakan bicara atau bahasa ekspresif adalah kemampuan mengucapkan bunyi-bunyi artikulasi atau kata-kata untuk mengekspresikan, menyatakan serta menyampaikan pikiran, gagasan dan perasaan.

Menurut Vygotsky $^{11}$ mulanya bahasa dan pikiran anak berbeda, kemudian perlahan sesuai tahap perkembangan mentalnya, bahasa dan pikiran menyatu sehingga bahasa merupakan ungkapan dari pikiran. Anak secara alami belajar bahasa dari interaksinya dengan orang lain untuk berkomunikasi, yaitu menyatakan pikiran

10 Suhartono. 2005. Pengembangan Keterampilan Bicara Anak usia Dini. Jakarta: Depdiknas.hal20

${ }^{11}$ Suyanto. 2005. Konsep Dasar Pendidikan Anak Usia Dini. Jakarta: Depdiknas.hal171-172 


\begin{tabular}{|l|l|r|}
\hline A1 Fitrah & \\
Journal Of Early Childhood Islamic Education & Kurangnya Bahasa Ekspresi Pada Anak \\
ISSN $:$ 2599-2287 E-ISSN $:$ 2622-335X & Usia 5 Tahun ... \\
Vol.2 No.2 Januari 2019 & Septi Fitriani \\
\hline
\end{tabular}

dan keinginannya dan memahami pikiran dan keinginan orang lain. Oleh karena itu belajar bahasa yang paling efektif ialah dengan bergaul dan berkomunikasi dengan orang lain. Ditambahkan oleh Montessori ${ }^{12}$ ketika anak "belajar" bahasa melalui interaksi orang dewasa, anak-anak tidak hanya "mempelajari" redaksi kata dan kalimat, melainkan juga struktur kata dan kalimat itu sendiri. Pola perkembangan bahasa anak sebagian besar hanya bisa diperolah anak interaksi, percakapan maupun dialog dengan orang dewasa. Aktivitas inilah yang dapat membuat anak mendapatkan model berbahasa, memperluas pengertian, mencakup kosakata yang ekspresif dan menjadi motivasi anak-anak dalam berinteraksi dengan orang lain atau kehidupan sosial. Pengembangan bahasa yang terbaik adalah ketika anakanak bertindak sebagai rekan percakapan dan masuk ke dalam pembicaraan atau dialog yang sebenarnya.

Bahasa merupakan sarana yang sangat penting dalam kehidupan anak maka perlu dikembangkan pada anak didik sejak usia Taman Kanak-Kanak. Berdasarkan uraian diatas dapat disimpulkan bahwa kemampuan bahasa ekspresif muncul dalam bentuk kemampuan berbicara dan menulis. Kemampuan yang utama untuk dikembangkan diusia dini adalah kemampuan berbicara. Berbahasa ekspresif atau mengungkapkan bahasa bagi anak artinya bukan hanya mengeluarkan suara atau bunyi tetapi bagaimana anak menyatakan keinginan, kebutuhan, pikiran dan perasaan kepada orang lain secara lisan.

12 Suyadi. 2010. Psikologi Dasar PAUD. Yogyakarta: Pedagogia.hal97 $\begin{array}{ccc}\text { Perkembangan Bahasa } & \text { Ekspresif } \\ \text { Somantri }^{13} \text { menyatakan } & \text { bahwa }\end{array}$ perkembangan bahasa anak TK berada pada fase praoperasional. Pada fase ini bahasa anak mulai tumbuh dan berkembang mengikuti pola berpikir menggunakan symbol-simbol yang mewakili suatu objek dan simbol-simbol itu dapat berupa mimik, gambar, citra atau bahasa. Perkembangan bahasabahasa pada fase ini, anak telah mampu memikirkan sesuatu objek tanpa kehadiran objek itu, serta mampu memikirkan masa lampaunya. Guru berperan untuk memotivasi anak untuk mengatur daya nalar anak agar terarah dengan baik.

Saat pembelajaran bahasa guru dapat membangkitkan emosional dan daya estetika anak dengan gerak mimik, bermain boneka tangan, pantomim dan lain-lain. Berbicara adalah suatu alat yang digunakan untuk menunjukan, menyatakan serta mengkomunikasikan pikiran, ide maupun perasaan. Ada dua tipe perkembangan berbicara anak: 1) Egosentric Speech, terjadi ketika anak berusia 2-3 tahu, dimana anak berbicara kepada dirinya sendiri (monologi). Perkembangan berbicara anak dalam hal ini sangat berperan dalam mengembangkan kemampuan berpikirnya; 2) Socialized Speech, terjadi ketika anak berinteraksi dengan temannya ataupun lingkungannya. fungsinya sebagai pengembangaan kemampuan anak dalam berosialisasi.

Kemudian socialized speech terdapat dalam lima bentuk yaitu: a) berbagi informasi untuk tujuan bersama, b)

13 Mustakim. 2005. Peranan Cerita dalam Pembentukan Perkembangan Anak TK. Jakarta: Depdiknas.hal29 


\begin{tabular}{|l|l|r|}
\hline & Al Fitrah & \\
Journal Of Early Childhood Islamic Education & Kurangnya Bahasa Ekspresi Pada Anak \\
ISSN : 2599-2287 E-ISSN : 2622-335X & Usia 5 Tahun ... \\
Vol.2 No.2 Januari 2019 & Septi Fitriani \\
\hline
\end{tabular}

penilaian terhadap ucapan atau tingkah laku orang lain, c) perintah, permintaan, ancaman, d) pertanyaan dan 5) jawaban ${ }^{14}$ Tahapan perkembangan awal ujaran anak menurut Pateda ${ }^{15}$ yaitu: 1) tahap penamaan, yaitu tahapan saat anak mulai mampu mengujarkan urutan bunyi kata tertentu dan anak belum mampu untuk memaknainya; 2) tahap telegrafis, pada tahapan ini sudah mulai bisa menyampaikan pesan yang diinginkannya dalam bentuk urutan bunyi yang berwujud dua atau tiga kata dan; 3) tahap transformasional, pengetahuan dan penguasaan kata-kata tertentu yang dimiliki anak dapat dimanfaatkan untuk mengucapkan kalimat-kalimat yang lebih rumit.

Anak yang berumur lima tahun adalah sudah mulai memberanikan diri untuk bertanya, menyuruh, menyanggah dan menginformasikan sesuatu. Berbagai kegiatan anak dikomunikasikan atau diujarkan melalui kalimat-kalimat. Disini anak sudah mulai berani mentransformasikan idenya kepada orang lain dalam bentuk kalimat yang beragam. Pencapaian perkembangan bahasa ekspresif anak taman kanak-kanak kelompok A rentang usia 4 - 5 tahun dalam Permendiknas no. 58 tahun 2009 yaitu: 1) mengulang kalimat sederhana; 2) menjawab pertanyaan sederhana; 3) mengungkapkan perasaan dengan kata sifat (baik, senang, nakal, pelit, baik hati, berani, baik, jelek, dsb.); 4) menyebutkan kata-kata yang

14 Nurbiana, Dhieni. 2006. Metode Pengembangan Bahasa. Jakarta: Universitas Terbuka.hal3.6

15 Suhartono. 2005. Pengembangan Keterampilan Bicara Anak usia Dini. Jakarta: Depdiknas.hal49 dikenal; 5) mengutarakan pendapat kepada orang lain; 6) menyatakan alasan terhadap sesuatu yang diinginkan atau ketidaksetujuan; 7) menceritakan kembali cerita/dongeng yang pernah didengar ${ }^{16}$ Mencermati paparan diatas dapat disimpulkan bahwa perkembangan bahasa ekspresif anak berkembang dengan pesat, dimana saat ini anak mulai memiliki banyak pertanyaan tentang lingkungannya. Anak juga mulai memiliki kepercayaan diri untuk mengungkapkan pikiran dan perasaannya. Anak mulai mengenal kata sifat, benarsalah, baik-buruk, memiliki banyak kosakata dan mulai menyatakan ketidaksetujuan terhadap suatu hal yang tidak disukainya. Mengembangkan keterampilan bicara anak berarti juga menyunting bahasa anak. Anak-anak membutuhkan penyuntingan bahasa. ${ }^{17}$

\section{Pentingnya Pengembangan Kemampuan Bahasa Ekspresif pada anak}

Suhartono ${ }^{18}$ mengemukakan bahwa anak usia dini melakukan aktivitas berbahasa yakni mendengarkan dan berbicara, oleh karena itu perlu dibina dan dikembangkan kemampuan bahasa reseptif dan ekspresifnya. Pengembangan bicara anak yang dimaksud adalah usaha meningkatkan kemampuan anak untuk berkomunikasi secara lisan sesuai dengan situasi yang dimasukinya. Pengembangan

16 Depdiknas. 2009. Permendiknas No. 58 Tahun 2009 tentang Standar Pendidikan Anak Usia Dini. Jakarta: Depdiknas.Hal10-11

17 Jan Dargatz, 52 Cara Membangun Harga Diri dan Percaya Diri Anak, ( Jakarta: Pustaka Tangga, 2007), hal. 43.

18 Suhartono. 2005. Pengembangan Keterampilan Bicara Anak usia Dini. Jakarta: Depdiknas.hal7 


\begin{tabular}{|l|l|r|}
\hline A1 Fitrah & \\
Journal Of Early Childhood Islamic Education & Kurangnya Bahasa Ekspresi Pada Anak \\
ISSN $:$ 2599-2287 E-ISSN $:$ 2622-335X & Usia 5 Tahun ... \\
Vol.2 No.2 Januari 2019 & Septi Fitriani \\
\hline
\end{tabular}

kemampuan bicara anak pada dasarnya merupakan program kemampuan berpikir logis, sistematis, dan analitis dengan menggunakan bahasa sebagai alat untuk mengungkapkan gagasannya.

$$
\text { Menurut Hurlock }{ }^{19} \text { memacu }
$$

kemampuan berbicara anak merupakan sesuatu yang penting. Kemampuan berbicara sangat mempengaruhi penyesuaian sosial dan pribadi anak. Pertama, anak yang pandai berbicara akan memperoleh pemuasan kebutuhan dan keinginan. Anak dapat menyampaikan apa yang dibutuhkan dan diinginkannya kepada orang lain. Kedua, untuk menarik perhatian orang lain. Hal ini penting karena pada hakikatnya anak suka menjadi pusat perhatian sekitarnya. Ketiga, anak yang pandai berbicara mampu membina hubungan dengan orang lain dan dapat memerankan kepemimpinannya. Keempat anak yang pandai berbicara akan memperoleh penilaian baik, kaitannya dengan isi dan cara berbicara. Kelima, anak yang pandai berbicara akan memiliki kepercayaan diri dan penilaian diri yang positif. Keenam, anak yang pandai berbicara biasanya mempunyai kemampuan akademik yang lebihh baik. Ketujuh, anak yang pandai berbicara lebih mampu memberikan komentar positif. Kedelapan, anak yang pandai berbicara cenderung pandai mempengaruhi dan meyakinkan teman sebayanya. Hal ini mendukung anak sebagai pemimpin.

Upaya pengembangan kemampuan berbahasa yang dilakukan terhadap anak usia Taman Kanak-kanak menurut

19 Hurlock, Elizabeth. 1978. Child Development Sixth Edition. Jakarta: Erlangga.hal178
Direktorat Pembinaan TK dan $\mathrm{SD}^{20}$ dilakukan dengan tujuan sebagai berikut : 1) agar anak dapat mengolah kata secara komprehensif; 2) agar anak dapat mengekspresikan kata-kata dalam bahasa tubuh yang dapat dipahami oleh agar anak mengerti setiap kata yang didengar dan diucapkan, mengartikan dan menyampaikan secara utuh kepada orang lain; 4) supaya anak dapat memberikan oendapatnya dan meyakinkan pendapatnya dengan pemilihan kata yang tepat.

Perkembangan bahasa anak meliputi perkembangan fonologis yaitu mengenal dan memproduksi suara, perkembagan kosakata, perkembangan simentik perkembangan penyususnan kalimat dan perkebangan pengunaan bahasa. ${ }^{21}$

Berdasarkan uaian diatas dapat kita simpulkan bahwa betapa pentingnya kita untuk menstimulasi bahasa eksperif anak mengungkapkan apa yang dia ingin katakan sesuia dengan pikirannya, serta anak dapat bersosialisasi dengan baik ketika anak memiliki bahasa yang baik.

\section{Faktor-Faktor Permasalahan Ekspresif Anak}

\section{Faktor Internal}

Salah satu faktor-faktor permasalahan Ekspresip anak adalah faktor internal yang menjadi faktor penyebab keterlambatan bicara pada anak sebagai berikut:

20 Direktorat Pembinaan TK dan SD. 2007. Pedoman Pembelajaran Persiapan Membaca dan Menulis Permulaan melalui Permainan di Taman Kanak-Kanak. Jakarta: Depdiknas. Hal3

21 Taskiroatun Musfiroh. 2008. Memilih menyusun dan menyajikan cerita untuk anak usia dini, Yogyakarta:Tiara Wacana.hal 7 


\begin{tabular}{|l|l|r|}
\hline & Al Fitrah & \\
Journal Of Early Childhood Islamic Education & Kurangnya Bahasa Ekspresi Pada Anak \\
ISSN : 2599-2287 E-ISSN : 2622-335X & Usia 5 Tahun ... \\
Vol.2 No.2 Januari 2019 & Septi Fitriani \\
\hline
\end{tabular}

\section{Kognisi}

Anak pada usia ini sangat aktif mengatur pengalamannya ke dalam kelompok umum maupun konsep yang lebih besar. Anak belajar mewakilkan, melambangkan ide dan konsep. Kemampuan ini merupakan kemampuan kognisi dasar untuk pemberolehan bahasa anak.

\section{Genetik}

Berbagai penelitian menunjukkan, bahwa gangguan bahasa merupakan kecendrungan dalam suatu keluarga yang dapat terjadi sekitar 40\% hingga 70\%. Anak yang memiliki ganguan bahasa bisa jadi karena keturunan dari anggota keluarganya yang memiliki ganguan. Mungkin sulit mengetahui berapa banyak transmisi intergenerasi gangguan bahasa tersebut, disebabkan oleh kurangnya dukungan lingkungan terhadap bahasa. Contoh banyaknya kasus yang di laporkan setidaknya $28 \%$ sampai $60 \%$ anak dengan ganguan bicara memiliki orang tua yang mengalami kesulitan bicara dan. anggota keluarga laki-laki lebih berpengaruh dari pada wanita. Bagaimanapun, data terbanyak memperlihatkan anak-anak dengan hanya gangguan bahasa saja dan tidak pada anak dengan gangguan bicara terpisah (isolated speech disorders).

Anak-anak dengan riwayat keluarga positif terhadap gangguan bicara akan membentuk grup spesifik ke dalam populasi gangguan bicara. Penemuan mereka tidak mendukung hipotesa karena tidak ada perbedaan bermakna yang ditemukan pada pengukuran artikulasi, fonologi, bahasa, kemampuan-kemampuan oral-motor atau kemampuan membaca dan menulis diantara anak-anak yang memiliki riwayat keluarga dengan gangguan bicara dibanding yang bukan. Disini dapat disimpulkan bahwa riwayat keluarga dengan gangguan bahasa bisa dipertimbangkan sebagai faktor risiko yang dapat digunakan untuk identifikasi awal.

Riwayat keterlambatan bicara yang dimiliki keluarga maka anak akan beresiko mengalami keterlambatan bicara . Riwayat keluarga yang dimaksud antara lain anggota keluarga yang mengalami keterlambatan berbicara, memiliki gangguan bahasa, gangguan bicara atau masalah belajar.

\section{Prematuritas}

Penyebab khusus berkaitan antara permasalahan periode pre atau perinatal dengan gangguan bicara dan bahasa juga telah dibuktikan. Ketika anak selama dalam kandungan mengalami Infeksi, imaturitas dan berat badan lahir rendah akan memengaruhi perkembangan bahasa pada anak.

Byers-Brown mengemukakan bahwa adanya keterlambatan proses pengeluaran suara dalam bicara pada bayi prematur. adanya faktor-faktor yang berhubungan dengan prematuritas yang mempengaruhi perkembangan bahasa anak, seperti berat badan lahir, perawatan intensif di rumah sakit, serta kondisi saat keluar rumah sakit.

\section{Faktor Eksternal (Faktor Lingkungan)}

Faktor lingkungan termasuk yang paling menentukan. lingkungan tempat anak dibesarkan menjadi salah satu faktor penting yang memengaruhi perkembangan bahasa anak. Lingkungan yang tidak memiliki situasi yang mendukung untuk pertumbuhan serta perkembangan anak 


\begin{tabular}{|l|l|r|}
\hline A1 Fitrah & \\
Journal Of Early Childhood Islamic Education & Kurangnya Bahasa Ekspresi Pada Anak \\
ISSN $:$ 2599-2287 E-ISSN $:$ 2622-335X & Usia 5 Tahun ... \\
Vol.2 No.2 Januari 2019 & Septi Fitriani \\
\hline
\end{tabular}

akan sangat mempengaruhi perkembangaan anak seperti ganguan lingkungan akan sangat mengangu pertumbuhan serta perkembangan anak seperti perkembangan bahsa anak.

\section{Pola asuh}

Law dkk ${ }^{22}$ mengemukanan bahwa anak yang menerima komunikasi yang tidak bagus dari keluarga, tidak memiliki teman untuk berkomunikasi serta berinteraksi akan mempunyai kemampuan bahasa yang rendah dibandingkan anak lainnya yang memiliki komunikasi yang baik dengan keluarga serta memiliki teman untuk berinteraksi dan berkomunikasi secra langsung

\section{Lingkungan verbal}

Lingkungan verbal mempengaruhi proses belajar bahasa anak. Anak yang tumbuh di lingkungan keluarga yang memilki lingkungan verbal yang baik, bembelajaran kata-kata yang didapat anak pun akan lebih baik dibandingkan anak yang dibesarkan dalam keluarga dengan kemampuan verbal lebih rendah. Dalam berbagai penelitian menunjukan ibu dengan tingkat pendidikan rendah serta kemampuan berbahasa renda merupakan faktor risiko keterlambatan bahasa pada anaknya.

Hasil dari beberapa Penelitian menyatakan bahwa keluarga sebagai pendidik pertama bagi anak memilki peran penting yang meengaruhi perkembangan bahasa anak. Komunikasi yang dilaksanakan secar intens antara anak dan keluarga. Penyebab permaslahan bahasa adalah kemiskinan megapa begitu?. Karena

${ }^{22}$ Law J, Bowle J, Harris F, Harkness A, Nye C., Screening for speech and language delay; a systematic review of literature, In: Health Technology Assessment 1998 Vol2(9). semakin tingginya tingkat kemiskinan pada keluarga akan menyebabkan berbagai permasalahan dalam rumah tangga seperti masalahan kesehatan seperti malnutrisi, gangguan kesehatan mental dan kurang perhatian serta ketidak-teraturan perawatan dari orang tua, menjadi salah satu penyebab permasalahan bahasa bagi anak. ${ }^{23}$

Sameroff dalam model penelitiannya menunjukkan beberapa faktor risiko sosial dan keluarga diantaranya adalah: masalah-masalah kesehatan mental ibu, kecemasan ibu, sikap otoriter ibu dalam mengasuh anak, hubungan ibu-anak yang buruk, pendidikan ibu yang kurang dari menengah atas, orang tua yang kurang atau tidak memiliki ketrampilan dalam pekerjaan, status etnik minoritas, tidak ada bapak, beberapa tekanan kehidupan tahun terdahulu, dan ukuran keluarga yang besar.

faktor tersebut dalam rangkaian individu yang berkaitan dengan nilai IQ anak-anak pada usia 4 tahun dan sebagian besar mayoritas masih berhubungan dengan IQ pada usia 13 tahun. Selain itu, jumlah faktor risiko sebagaimana didefinisikan oleh risiko kumulatif dalam, adalah prediktor kuat IQ pada usia 4 tahun dengan $58 \%$ dan pada umur 13 dengan varians $61 \%$.

\section{Otitis media}

Menurut Grievink didapatkan sekitar 80\% dari seluruh anak prasekolah mengalami satu atau lebih episode otitis media Akut atau otitis media effusion Selama episode ini, anak-anak mengalami fluktuasi kehilangan pendengaran, biasanya antara $20 \mathrm{~dB}$ dan $50 \mathrm{~dB}$. Dari penilitian

23 Moeslichatoen. Metode Pengajaran Ditaman kanak-kanak. Jakarta:Rineka Cipta. Hal 91 


\begin{tabular}{|l|l|r|}
\hline & Al Fitrah & \\
Journal Of Early Childhood Islamic Education & Kurangnya Bahasa Ekspresi Pada Anak \\
ISSN : 2599-2287 E-ISSN : 2622-335X & Usia 5 Tahun ... \\
Vol.2 No.2 Januari 2019 & Septi Fitriani \\
\hline
\end{tabular}

Gravel dan Nozza gangguan tersebut mempengaruhi jumlah dan kualitas bicara dan bahasa yang didengar.

\section{Anamnesis}

Anamnesis menjadi salah satu penyebab ganguan bahasa pada anak Beberapa pertanyaan yang dapat ditanyakan antara lain:

- Pada usia berapa bayi mulai mengetahui adanya suara, misalnya dengan respon berkedip, terkejut atau mengerakkan bagian tubuh

- Pada usia berapa bayi berkomunikasi dengan cara merespon dengan seyuman.

- Kapan bayi mulai mengeluarkan su ara "aaaggh".

- Orientasi terhadap suara, misalnya bila ada suara apakah bayi memalingkan atau mencari arah suara.

- Kapan bayi memberi isyarat dan be rmain cikkebum.

- Mengikuti perintah satu langkah, se perti “beri ayah sepatu” atau "ambil koran”.

- Berapa banyak bagian tubuh yang dapat ditunjukan oleh anak, seperti mata, hidung, kuping dan sebagainya.

\section{Pembahasan}

\section{Hasil Penelitian}

Observasi yang saya laukan pada tanggal 25 November kepada AP, tempat tanggal lahir: Bengkulu 2801 2014, Syahdan panggil kecilnya, ketika saya melakukan obeservasi hanya diam dan hanya sekali berbicara dan hanya mengucapkan kata-kata yang tidak jelas. Saya beberapa kali memanggil syahdan dia menoleh sebenttar dia akan lebih tertarik memainkan apa yang ada di sekitarnya dari pada menanggapi panggilan saya. saya mencoba membujuknya dengan menggunakan roti dia akan tetapi diam saja ketika saya tambah rotinya menjadi dua dia tetap dia dan sibuk memandangi saya untuk yang terakhir kalinya saya memberikan tiga roti syahdan mengeluarkan mimik muka menginginkan roti tersebut akan tetapi syahdan tidak mampu mengungkapkan melalui kata-kata di hanya tersenyum malumalu dan sibuk sendiri.

Saat itu syahdan sedang duduk diatas motor sesekali menyimak saya berbicara dengannya kemudian dia kan sibuk sendiri kembali, saat dia mencoba turun dari motor dan mengambil helm yang terletak diatas meja dekat motor tersebut hingga ada salah satu temanya yang menaiki motor, syahdan merengek mencoba mengusir temanya, tanpa mengucapkan kata-kata apapun kecuali rengekan tidak jelas. Hingga akhirnya salah satu pekerja dari ibunya memisahkan mereka dengan cara menjauhkan anak tadi dari motor yang ingin syahdan naik'i.

Respon syahdan mengenai suatu perintah sangat pasif tidak ada kata-kata yang keluar dari mulutnya selama saya melakukan observasi, walaupun yang memerintahnya menyebutkan kata"ular" itu orang yang dekat dan selalu ia temui tiap hari dia akan tetap diam, tanpa mau merespon. Bermain bersama temantemanya pun syahdan hanya akan mengikuti teman-temanya berlarian tanpa akan mengeluarkan suara akan tetapi jika ada yang mengangu ia akan merengek atau bermain sendiri. 


\begin{tabular}{|l|l|r|}
\hline A1 Fitrah & \\
Journal Of Early Childhood Islamic Education & Kurangnya Bahasa Ekspresi Pada Anak \\
ISSN $:$ 2599-2287 E-ISSN $:$ 2622-335X & Usia 5 Tahun ... \\
Vol.2 No.2 Januari 2019 & Septi Fitriani \\
\hline
\end{tabular}

Saat saya mendengar ibunya bicara ternyata ibunya memiliki permasalahan bahasa cadel serta kurang ekspesif juga. itulah hasil penelitian yang saya lakukan pada adek syahdan.

Bromley $^{24}$ menyatakan kemampuan berbicara merupakan suatu ungkapan dalam bentuk kata-kata. bahasa ekspresif adalah berbicara dan menuliskan informasi untuk dikomunikasikan dengan orang lain, seedangkan syahdan hanya akan diam ketika diajak berkomunikasi serta hanya menampilkan mimik muka ingin ketika ditanya apakan ia mengiginkan roti. Gordon dan Browne dalam Dhieni ${ }^{25}$ menambahkan bahwa penguasaan berbahasa ekspresif adalah semakin seringnya anak menyatakan keinginan, kebutuhan, pikiran dan perasaan kepada orang lain secara lisan. Tetapi syahdan hanya merengek kita dia digangu atau ada hal yang ia tak sukai.

Menurut Steinberg dan Gleason ${ }^{26}$ Kemampuan bahasa ekspresif anak diusia 3-5 tahun termasuk dalam perkembangan kombinatori dimana anak sudah mampu berbicara secara teratur dan terstruktur, pembicaraannya dapat dipahami oleh orang lain dan anak sanggup merespon baik positif maupun negatif atas pembicaraan lawan bicaranya. Respon yang di berikan syahdan hanya dengan dia dan memainkan apa yang ada disekitarnya tanpa mau

24 Nurbiana, Dhieni,. 2006. Metode Pengembangan Bahasa. Jakarta: Universitas Terbuka.hal19

25 Nurbiana, Dhieni,. 2006. Metode Pengembangan Bahasa. Jakarta: Universitas Terbuka. 7.5

26 Suhartono. 2005. Pengembangan Keterampilan Bicara Anak usia Dini. Jakarta: Depdiknas.Hal 35 merespon pembicaraan saya dengan lisan Dengan hal ini dapat disimpulkan AP mengalami ganguan Bahasa Ekspresif karena ketidak mampuanya mengucapkan mengespresikan serta berkomunikasi mengenai apa yang ia inginkan.

\section{Faktor-Faktor Permasalahan Ekspresif Faktor Internal, Genetik}

Seperti disebutkan gangguan bahasa merupakan kecendrungan dalam suatu keluarga yang dapat terjadi sekitar 40\% hingga 70\%. Anak yang memiliki ganguan bahasa bisa jadi karena keturunan dari anggota keluarganya yang memiliki ganguan. Disini ibunda dari Syahdan sendiri memiliki ganguan bahasa ibundanya cadel dan kurang jelas ketika berbica serta kurang ekspresif dalam berkomunikasi. Sehingga salah sartu yang menyebabkan sayahdan mengalami permasalahan bahasa yaitu faktor genetik atau keturunan

\section{Faktor Eksternal (Faktor Lingkungan) Pola asuh}

Seperti yang dikemukaan oleh Law dkk 27 bahwa anak yang menerima komunikasi yang tidak bagus dari keluarga, tidak memiliki teman untuk berkomunikasi serta berinteraksi akan mempunyai kemampuan bahasa yang rendah dibandingkan anak lainnya yang memiliki komunikasi yang baik dengan keluarga serta memiliki teman untuk berinteraksi dan berkomunikasi secra langsung. Syadhan tidak memiliki teman sebaya di lingkungan rumahnya jadi syahdan hanya berinteraksi dengan ibu, ayah dan adiknya saja.

${ }^{27}$ Law J, Bowle J, Harris F, Harkness A, Nye C., Screening for speech and language delay; a systematic review of literature, In: Health Technology Assessment 1998 Vol2(9). 


\begin{tabular}{|l|l|r|}
\hline & Al Fitrah & \\
Journal Of Early Childhood Islamic Education & Kurangnya Bahasa Ekspresi Pada Anak \\
ISSN : 2599-2287 E-ISSN : 2622-335X & Usia 5 Tahun ... \\
Vol.2 No.2 Januari 2019 & Septi Fitriani \\
\hline
\end{tabular}

Dengan ini dapat disimpulkan bahwa AP mengalami ganguan permasalahan bahasa ekspresif faktor penyebabnya yaitu faktor internal dari genetika ibunya juga mengalami ganguan bahasa dan internal dari lingkungan karena tidak ada teman sebaya untuk bermain saat umur 1-4 tahun.

\section{Penutup}

Berdasarkan hasil penelitian dan pembahasan disimpulan bahwa, bahwa “AP” umur 5 tahun benar-benar mengalami masalah ganguan ekspresif, belum lagi cara pengucapan kurang jelas dan hanya berbicara dengan gumaan saja, belum dapat mengadakan dialog atau berkomunikasi, belum dapat memberikan informasi, mengucapkan keinginannya pada saat frustasi dengan kalimat yang tidak utuh. Serta yang mempengaruhi tergangunya bahasa ekspresif SP dikarenakan foktor internal yaitu genetik yaitu karena ibunya memiliki ganguan berbahasa dimana sang ibu juga memiliki permaslahan yaitu agak cadel dalam berbicara, kemudian faktor eksternal yaitu faktor lingkungan dimana SP tidak memiliki teman sebaya saat berumur 1-4 tahun, menjadikan SP kurang dalam berkomunikasi. Kemudian ia juga kurang diajak berkomunikasi oleh keluarga karena ibunya kurang banyak bicara, serta ayahnya yang sibuk bekerja Sehingga adek syahdan mengalami ganguan bahasa ekspresif . itulah kesimpulan saya dari observasi yang saya lakukan kepada AP

\section{DAFTAR PUSTAKA}

Arikunto, Suharsimi. 2013. Prosedur Penelitian: Suatu Pendekatan Praktek.Jakarta:Rineka Cipta.

Depdiknas. 2009. Permendiknas No. 58 Tahun 2009 tentang Standar Pendidikan Anak Usia Dini. Jakarta: Depdiknas.

Dhieni, Nurbiana. 2006. Metode Pengembangan Bahasa. Jakarta: Universitas Terbuka.

Direktorat Pembinaan TK dan SD. 2007. Pedoman Pembelajaran Persiapan Membaca dan Menulis Permulaan melalui Permainan di Taman Kanak-Kanak. Jakarta: Depdiknas.

Hurlock, Elizabeth. 1978. Child Development Sixth Edition. Jakarta: Erlangga.

Jannah Rina Roudhotul,dkk.2018. Strategi Pembelajaran Anak Usia Dini Berbasis Multiple Intelligences. Jakarta:Ar-ruzz Media

Jan Dargatz, 52 Cara Membangun Harga Diri dan Percaya Diri Anak, ( Jakarta: Pustaka Tangga, 2007), hal. 43.

Law J, Bowle J, Harris F, Harkness A, Nye C., Screening for speech and language delay; a systematic review of literature, In: Health Technology Assessment 1998 Vol2(9)

Musfiroh, Taskiroatun. 2008. Memilih menyusun dan menyajikan cerita untuk anak usia dini, Yogyakarta:Tiara Wacana.

Musfiroh, T. 2005. Bercerita Untuk Anak Usia Dini. Jakarta: Depdiknas. 


\begin{tabular}{|l|l|r|}
\hline A1 Fitrah & Kurangnya Bahasa Ekspresi Pada Anak \\
Journal Of Early Childhood Islamic Education & Usia 5 Tahun ... \\
ISSN $:$ 2599-2287 E-ISSN : 2622-335X & Septi Fitriani \\
Vol.2 No.2 Januari 2019 & \\
\hline
\end{tabular}

Mustakim. 2005. Peranan Cerita dalam Pembentukan Perkembangan Anak TK. Jakarta: Depdiknas.

Moeslichatoen. Metode Pengajaran

Ditaman kanak-kanak.

Jakarta:Rineka Cipta.

Otto, Beverly.2015. Perkembangan Bahasa

Anak Usia

Dini.Jakarta:Prenadamedia Grub.

Semiawan, Conny R. 2010. Metode

Penelitian Kualitatif.

Cikarang:Grasindo.

Suhartono. 2005. Pengembangan

Keterampilan Bicara Anak usia

Dini. Jakarta: Depdiknas.

Sugiyono. 2008. Metode Penelitian

Pendidikan ( Pendekatan

Kuantitatif, Kualitatif dan R\&D).

Jakarta:Alfabeta.

Suyadi. 2010. Psikologi Dasar PAUD.

Yogyakarta: Pedagogia.

Suyanto. 2005. Konsep Dasar Pendidikan

Anak Usia Dini. Jakarta:

Depdiknas.

Tarigan, H.G. 2008. Berbicara sebagai

Suatu Keterampilan Berbahasa.

Bandung: Angkasa. 